Preliminary communication UDC111.84(045)

doi: $10.21464 / \mathrm{sp} 32103$

Received: February $14^{\text {th }}, 2017$

\author{
Luka Janeš \\ University of Zagreb, University Centre for Integrative Bioethics, Ivana Lučića 1a, HR-10000 Zagreb \\ ljanes@unizg.hr
}

\title{
Paradogma of the Psychic Entropy of Evil and the Palingenesis of All-Oneness
}

\begin{abstract}
Objective of this paper is to indicate inadequate general theoretical approach to the perception of evil, which in return contributes to the permanence of "evil in the world". Analysis will focus on the logially imprecisely adopted and observed anthropocentric and romantic relation between good and evil through debatable pairs of notions such as virtue-sin, heaven-hell, white-black et cetera. I will lay out concepts that interpret evil as a priori psychic and epistemic phenomenon producing moral issues by the transmutation via mentioned pairs. It appears in the framework of social (political) community as the ratio of the energy of "openness" and "closeness". With this pair I replace all the traditional pairs, and I further describe it on the grounds of the analysis of narcissism. I understand narcissism as being one of the results of the lack of knowledge potentiated by fury and fear in the relation to the self. It prevents us from knowing All-Oneness, a mereological principle that takes into consideration the entire biotic community. Expected contribution consists of pointing at the methods for the reduction of evil in the world.
\end{abstract}

\section{Keywords}

psychic entropy, All-Oneness, narcissism, evil, mereology, openness, closeness, luminance, integrative bioethics

\section{Terminological and methodological issues: preliminary overview}

Historically and philosophically captivating, the problem of evil is one of the most discussed topics to date, but strangely enough, also a permanent taboo. And while its aporia of crime and punishment in this world or in the aftermath is certainly symbolically bewitching, I claim that categories playing the role in understanding of this aporia are not adequately precise, thus our use of these categories is nihilating the potentiality of nullifying the level of normality present in our moral reflection regarding existence of evil. In this paper, I will tackle the categories exclusively, avoiding case studies of particular crimes throughout the history for two reasons: because their quantity is endless and their existence apparent, and because I believe we will have a better use of this study if analysing the categorical causality behind the crimes will be its telos. Moreover, this paper has an intention to be a propaedeutics to studying All-Oneness, ${ }^{1}$ that is, to studying the psyche as the dialectical 1

When I use the term All-Oneness, I refer to the conceptual and factual totality of biotic and abiotic community of cosmos. Similar concepts are present throughout the history of philosophy, from Heraclitus and Plotinus to Carl Gustav Jung, and they find support in 
synthetic force within the sphere of living beings. To make my case clearer, consider Svendsen's observation:

“... the idea of evil was seen as a holdover from a mythical, Christian worldview whose time was already past. Initially, as I began to attempt this 'rehabilitation' of the concept of evil, the idea itself was still an object of fascination for me. This fascination was a result, most especially, of our tendency to regard evil as an aesthetic object, where evil appears as something other and therefore functions as an alternative to the banality of everyday life. We are steadily exposed to more and more extreme representations of evil in films and such, but this form of evil doesn't belong to a moral category. Like most other things in our culture, evil has been aestheticized." 2

Although I agree with the argument Svendsen made regarding perception of evil as being shifted into the domain of aesthetics, I cannot agree with him that aesthetics is the context from which we should draw our answers from. My question would be - why aesthetics? - and I would look for the answer in the causality anterior to aesthetical dimension of the phenomena. In my attempt to clarify the issues regarding the problem of evil, in focus of this paper I will discuss in parallel the micro-level of evil-doing in the psyche of the individual, and meso-level of evil-doing within society, while macro-level of this discussion will be indirectly implied as the mereological co-bearing of the All-Oneness. Mereology is a mathematical discipline which studies the relation of parts and the wholes they form. Here I draw from the general idea the concept of the mereology of community (society) because of its heuristic power, the ability to grasp the complexity of contexts, that is, of particular constellations building next levels of the whole. In a different context but similar sense, Matjaž Potrč concluded the following:

"Thus far we claimed that the science of wholes and parts, that is mereology, is fundamental for phenomena. In Greek, meros means a part. Mereology is fundamental for the study of phenomena, that is, phenomenology. Phenomena is crucial for the study of ways in which the whole appears." ${ }^{3}$

However, prior to any viable discussion in the given context, there are terminological and methodological issues that need to be addressed.

Consistency of the permanence of evil in the world influenced me to believe that there is something misleading in moral(izing) interpretations of the evildoing. The historical situation continues to lead us to falsely believe that the existence of evil in the world is normal, even necessary. I claim that there is something one-dimensional in the general approach to the problem, in the way in which interpretations fail to contribute to the process of overcoming the conflicted state of the world. The problem with the way in which we think about the evil-doing is related to the way in which interpretations remain consistent with the terminological structure of the notion of moral, from the latin moralis, having a litteral meaning of "pertaining to ...". Similar connotation is present in the German version Sittlichkeit, in Croatian translated as "običajnost", both referring to the expected structured order of manners or character. All of them semantically disclose sedentarism, "being sitted-in" or "inseatedness". It implies passivity, it manifests dreamy inseatedness of the moral immutability which influences not just actions per se, but thinking about these actions. This leads us to another general problem with the analysis of evil, mainly the fact that we are too strongly focused on physical act of evil. We revolve around the terms such as "misconduct", "atrocity", "felony", and "crime", but this "evil-doing" is but an outcome of the "evil-bearing". Genesis of evil begins in the thoughts of beings, and, before any physical act performed upon others, it firstly manifests itself through speech. Of course, any speech act is surely physical, but that misses the point: poisonous edge 
to evil occurs in the initial transfer - in the thinking itself and in the communication between beings, most precisely - in the psyche of beings, which is the true carrier of the potentiality to do evil and to be evil. In fact, evil can be performed by not doing anything concrete, as Arendt implies through quoting Augustine of Hippo:

"The man who, knowing the right, fails to do it, loses the power to know what is right; and the man who, having the power to do right, is unwilling, loses the power to do what he wills." ${ }^{4}$

In classical terms of understanding evil, this is not something to be understood as evil - and that is precisely the problem because this is how evil is "born". Thus, before any discussion on morally problematic acts, we need to address the a priori epistemic - psychic - ground, which genealogically predates moral act, that is, constitutes moral reasoning. There is an element of learning involved with committing evil acts, a person learns about making herself the goal of any deed, including causing harm to others, actions which lead to establishing oneself as the knowledge paradigm for doing good. Baudrillard made a similar case when he concluded the following:

"Unintelligence of evil, absence of insight into things by evil and therefore always the same discourse on the 'foul beast' and the same naïveté in the analysis of present events. Our whole system of values excludes this predestination of evil. Yet all it has invented, at the end of its burdensome therapy on the human species, is another way of making it disappear, that is to say, of ironically carrying the possibility of happiness to its opposite term, that of the perfect crime, that of integral misfortune, which was somehow waiting for it just at the end."

The necessity by which misleading occurs, the perception that the appearance of absolute evil will happen, is empowered by an intuition that human beings are evil by nature, whether we are "tainted by the first sin" or we behave as if "one human being is a wolf to another". This kind of negative anthropology forces us to believe that we know ourselves as evil, and thus we orient ourselves only towards ourselves, giving birth to narcissism. A narcissist exhibits extreme selfishness and eventually fails to comprehend others as worthy on their own. She wants to be the subject of every situation, and attempts to be all the others who might challenge her agency, and thus works to mentally in-

the field of natural sciences, most notably in physics via discovery of the relation between elementary forces and the vacuum playing a constitutive role in the kinesis of the cosmos, but also in biology and chemistry in the context of evolutionary processes and self-organization of its internal movements. All-Oneness does not imply any type of anthropocentric god, it does not refer to one any being, rather, the notion implies the underlying unity within the totality, the unifying relations and the content of these relations between the aforementioned biotic and abiotic, but more specifically, between the physical and the mental or between the body and mind. It implies single unifying and unchanging truth, the kind Heraclitus spoke about, though not as "minervistic" records of the current, but as the creative, dynamical, and animating force. I think of it not as if it's a state-like totalitarity drowning variety into undifferentiated blob, but as the unity of phenomenological n-pluriaspects governed by the category of organism.
Lars Svendsen, Philosophy of Evil, translated by Kerri A. Pierce, Dalkey Archive Press, Champaigne, London 2010, p. 9.

3

Matjaž Potrč, Pojave i psihologija [Phenomena and Psychology], translated by Ksenija Premur, Lara, Zagreb 2017, p. 42.

4

Hannah Arendt, $O$ zlu. Predavanje o nekim pitanjima moralne filozofije [On Evil. Lectures on Certain Questions from the Philosophy of Morality], translated by Nadežda Čačinovič, Naklada Breza, Zagreb 2006, p. 103. The quotation is from St. Augustine's De libero arbitrio, 3.19 .53 .

5

Jean Baudrillard, The Intelligence of Evil or the Lucidity Pact, translated by Chris Turner, Berg, New York 2005, p. 174. 
fluence them to her bidding. Lacan describes an important aspect of narcissist in this way:

"I suggest that there is a radical distinction between loving oneself through the other - which, in the narcissistic field of the object, allows no transcendence to the object included - and the circularity of the drive, in which the heterogeneity of the movement out and back shows a gap in its interval." 6

Final outcome of this behaviour is the mereological collapse of the All-Oneness into a narcissist, into a singleton, who pseudo-logically behaves as if, and believes she is the All-Oneness. Narcissist encloses away the mereological richness of the totality of biotic and abiotic community, and because of this, narcissism can be considered the prime characteristic of human beings in general - as species. It is worthy to mention that the root meaning of narcissism - narke - means numbness, intoxication - and as such reflects our species as those who fell in love with themselves on account of the All-Oneness. Narcissism is the dominant opiate of our species, and was naively represented through psychology and psychiatry as a matter of individual cases, an anomaly. ${ }^{7}$ Narcissism plays a central role as a specific "meta-magnet" attracting numbness, greed, and moral relativism, it is a "mereological fissure" preventing us from attaining contextual unity beyond the unity of ourselves, while against it plays the disposition of thinking about others as a reflection of the All-Oneness we are a part of. Clearly, history showed us that by simply establishing a social contract we did not get far in solving the problem of permanence of evil. I believe that we can overcome these issues by thinking through the perspective of All-Oneness, yet only if we observe evil as the antithesis to the All-Oneness, and think of it as the absolute narcissism preventing the perception of the mereological eccentric positionality through the judgment of the energy ratio of openness and closeness. ${ }^{8}$ This is my first hypothesis, and by it I suggest to consider understanding interrelations within society as a "domain of energy" made of "atoms" in everlasting interactive movement. Harmony between the "atoms" is maintained by the energy of openness (the Good), while aporetic limitations and disorder are maintained by the energy of closeness (the Evil). What is required is the shift in the perspective, the clarification of the new form of the understanding of eccentric positionality (Plessner) as the continual transcending of the n-positions in which we are not subjects of anything, but pure predicates in relation to other "atoms" of community which we perceive as subjects. This subversion of the role of subject and object allows us to invest our energy of openness into prosperity for other members of the community who similarly strive to their telos, in return they do the same for us. On the micro-level, the relation between the two energies produces either stabile psyche of the individuals and a positive internal relation to oneself, or it produces "knots of energy" breeding anguish of ire, bitterness, and fear. ${ }^{9}$ From the perspective of practical solutions to the disorder, we are dealing with certain circulus vitiosis which amplifies psychic entropy of living beings - the process of "setting-apart", disharmonizing, depletion of openness into closeness. Jung explained the principle of entropy in the context of psyche in this way:

"Principe of entropy is from our experience known only as the principle of partial processes that represent a relatively closed system. We can observe psyche as one such system. (...) Since only relatively closed systems are available to our experience, nowhere are we in a situation to be able to observe the absolute psychic entropy. However, the stronger is the enclosing of psychic system, the stronger is the proof for phenomenon of entropy. [Jung's footnote 41 states the following: System is completely closed when outside input of energy is further not possible, only 
then entropy takes place] We can see this especially in cases of psychic disorders, characterized by the intense exclusion of outside world." 10

This begins not with acts, but with talking and thinking, and the negative energy - manifestation of closeness in the sense of constructing enclosures in the meso-level network of "energy relays" of co-existence - has fertile ground in the psyche of living beings. This interrelation, and the corruption of All-Oneness, does not refer only to human beings - it refers to all living beings, to the fullness of the biosphere and beyond, as all of the living or non-living units are unavoidably members of the mereology of All-Oneness. The positive totality, the outwardity of openness phenomenon, suggests to us that there might be a qualitative difference between evil (closeness) and good (openness). More precisely, that closeness is a deviant post-effect of the complexity of interrelations of the ever-opened totality. This influences our way of thinking about the method for preventing evil. Augustine of Hippo understood this well:

Jacques Lacan, The Seminar of Jacques Lacan. Book IV: The Four Fundamental Concepts of Psychoanalysis, translated by Alan Sheridan, W. W. Norton and Company, London 1998, p. 194.

7

Quite the opposite, I claim that history of humanity has the traits of narcissi-epidemic. Psychoanalysts provided somewhat better theories on narcissism, and there is a number of them. For example, Freud speaks of libidal narcissism, Abraham speaks of destructive narcissism, Kohut speaks of healthy narcissism, and Millon speaks of four type of narcissism: unprincipled, amorous, compensatory, and elitist. See Theodore Millon, Disorders of Personality. DSM-IV and Beyond, Wiley and Sons, New York 1996, especially p. 393. In DSM-V, classification of narcissism as a psychic disorder is identified in the following manner: "A pervasive pattern of grandiosity (in fantasy or behaviour), need for admiration, and lack of empathy, beginning at early adulthood and present in a variety of context (...)." See American Psychiatric Association, DSM 5, London 2013, p. 669. Diagnostics consists of nine key points. I selected some of the more intriguing ones: a grandiose sense of self-importance (i.e. exaggerates achievements and talents, expects to be recognised as superior without commensature achievements); has a sense of entitlement (i.e. unreasonable expectations of especially favourable treatment of automatic compliance with his or her expectations); is interpersonally exploitative; lack empathy: is unwilling to recognize or identify with the feelings and needs of others.

8

I devised the concept of the energy of openness and closeness inspired by the general hypothesis on openness and closeness proposed by Luka Perušić during a lecture at the international symposium "Rationality and the Prob- lem of Evil", held in Trogir from August 28 to September 3, and organized by the Croatian Dominican Province, Centre of Excellence for Integrative Bioethics (University of Zagreb), Ian Ramsey Centre for Science and Religion (University of Oxford), and Humane Philosophy Project. Perušić provided diachronic and synchronic synthesis of the approaches to the problem of evil, and has argued that the differences in understanding the problem of evil - thus the problem with solving it - comes from misunderstanding the manifestations of good and evil. They are emerging properties. More precisely, that they are in fact fully understandable through, and governed by, the higher relationship between openness (opening) as a phenomenon, and closeness (enclosing) as a phenomenon. By shifting the focus of discussion to the mechanism and structure of the coming-to-be of both good and evil, Perušić provided several examples of aporia solvable by this mechanism, including some classic issues such as the Kantian problem of "lying to the murderer at the door".

Dominant explanation on the purpose of fear is that it is a natural reaction to danger which developed through the process of evolution. Here, I focus more on the fear radicalized through the system of protection, an irrationality of self-love and self-indulgence which eventually grows into a threat to the being itself.

10

Karl Gustav Jung [Carl Gustav Jung], Dinami$k a$ nesvesnog [Dynamics of Unconscious], Matica srpska, Beograd 1978, p. 96. More precisely, Jung thinks about cases of affective numbness that results from schizophrenia, but I claim that this can, in a much broader sense, be considered in contrast to being fully aware of the All-Oneness. In the second chapter of this paper I will provide more arguments for this claim. 
"But evils are so thoroughly overcome by good, that though they are permitted to exist, for the sake of demonstrating how the most righteous foresight of God can make a good use even of them, yet good can exist without evil, as in the true and supreme God Himself, and as in every invisible and visible celestial creature that exists above this murky atmosphere; but evil cannot exist without good, because the natures in which evil exists, in so far as they are natures, are good. And evil is removed, not by removing any nature, or part of a nature, which had been introduced by the evil, but by healing and correcting that which had been vitiated and depraved." 11

The key moment of "healing" is, much as Augustine of Hippo did in his Confessions, communication. We should not be thinking about All-Oneness, openness and closeness as if they are pseudometaphysics of otherworldly, transcendent principles that imply static factuality, rather, both good and evil are dynamic communication of energy, a transfer of information from point A to point B. Evil occurs with closing of the information, with subjects communicating to themselves via others, instead of simply communicating to others in order to gain their own information, when behaving as if others are merely a subpoint of the absolute oneself in the mereology of relations. This type of behaviour is identifiable in most of the common evil-bearing acts: bullying the weaker, stealing, fraudulence, killing for pleasure or gain, falsifying history, truth or knowledge regarding e. g. god, taking advantage of the ill or disabled for gaining wealth et cetera. The problem is the level at which this type of behaviour occurs: it is the question not of the individuals, e.g. psychopaths, but of masses. They are governed by the intentional unconscious operating on the basis of intuited knowledge of the negative anthropology. ${ }^{12}$ All of them are driven by sentiments of anger and fear orienting around substitution of AllOneness for the self. Likewise, good occurs with opening the information, with being a point of progress for the whole and a gathering point for the particulars, with dedicating yourself to "midwifery", to mereological maieutic: instead of bullying the weaker, you offer your back to support her growth, and you teach her how to offer her back to the weaker, because although mereological nature of the All-Oneness strongly suggests hierarchy, there is, in fact, nothing such to it. Kant writes:

"The opposite of egoism can only be pluralism, that is, the way of thinking in which one is not concerned with oneself as the whole world, hut rather regards and conducts oneself as a mere citizen of the world."13

Finally, if evil can thus be understood as miscommunication, then we ought to dedicate our focus to the question of how knowledge is transferred and how does it "contribute" to the problems of psychic entropy. From slumber this wakens another problem which established itself in the past hundred years, which is a neglecting of the term psyche, and complete discoursive confusion of the terms "psyche", "spirit", "ghost", "reason", "mind", "soul", and "mental". For example, in psychology psyche is understood as the totality of conscious and non-conscious content, while in institutional psychiatry a "psychic disorder" is just an organic brain disorder, that is, disorder of the reason, meaning that "psyche" is limited to the aspects of the brain, while neuroscientists often equate brain with "mind" without giving much thought. Firstly, the problem is with the presupposed understanding of psyche by which it is empirically observable. Already Heraclitus understood the depth of psyche, claiming in fr. 35 that you cannot find its limits, ${ }^{14}$ which was something that Karl Jaspers outlined in the contemporary context:

"We can comprehend and study only that which for us became an object. Yet soul as such is not an object. It becomes an object in a sense in which it appears perceivable within the world: 
in accompanying somatic occurrences, in understandable expression, in behaviour, in actions - moreforth, it manifests itself in language communication, speaks of what it means and thinks, produces work. In all these facts, which are demonstrable in the world, effects of soul are laid before us, occurrences in which we directly perceive the soul, or on the basis of which we deduce regarding the soul. The soul itself is not our subject [object]. We experience it in us as a conscious experience and visualize the experience of the Other, be it from the objective phenomena or from reports of our own experiences. But that experience is an occurrence, too. We may let the soul become objectified through pictures and parables. However, it remains to be the all-encompassing which does not become an object, but rather out of which the individual facts become objective." 15

In more concrete sense, the problem occurs when we take a look at the use of these notions in the context of institutions: we have "mental" institutions, "psychic" institutions, "sanitariums", "bedlams", and "insane asylum", accompanied with derogatory terms such as "nuthouse", "funny farm", and "madhouse". In Croatian, a term "umobolnica", literally meaning "hospital for mind" or "hospital for reason", is occasionally still used "off the record". The problem is the following: patients are treated, and diseases understood depending on the semantic context of the notions in use. Can my issues be cured with chemicals, or by social support and care, that depends on what notions endow our reasoning, and thus the probable damage of the extension of confusion regarding the way we think about phenomena is not measurable, but it can certainly be imagined and should not be ignored. Much like body serves to produce and convert substances into energy, so does psyche produce and covert "cognitive" phenomena, such as will or emotion, into acts. What would happen to the current practice if, for example, we would restore the Ancient Greek understanding of psyche which rejected dualism of mind and body that became popular during Middle Age and would certainly reject the concept of either soul or mind being equal to brain functioning? In fact, Greeks in many ways argued the opposite, and psyche was related to breathing, blowing, taking of space, was understood as the principle of vitality, as psukhe literally meaning "breath", "life", and "soul". Democritus, for example, argued the following:

11

Augustine De Civ. 272. See Philip Schaff (ed.), St. Augustine's City of God and Christian Doctrine, translated by Philip Schaff, Christian Literature Publishing Co., New York 1890, p. 437.

12

Intentional unconscious is a term that was coined in collaboration with Luka Perušić. The goal was to find a suitable semantic image that explains the mereological agent of the action dynamics of both the unaware and aware subjects, of subjects that have no authentic understanding of the structure prior to the acts being undertaken, and whose mereological contribution is controlled by heterogeneity, but also of those who do yet cannot control this agency. They can be closely related to the social system of any particular ideology, but not necessarily - the processes are more fundamental than the meso-level of interaction, they can originate from within the beings without outside influence. This notion is somewhat complementary with the discussion regarding intentional unconscious- ness and unconscious intentionality as found in phenomenological research and in the research of mind, for example by John R. Searle and Carl Gustav Jung. This requires a different study altogether and hereforth is only referenced.

13

Immanuel Kant, Anthropology from a Pragmatic Point of View, translated by Robert B. Louden, Cambridge University Press, Cambridge 2006, p. 18.

14

"You will not find out the limits of the soul by going, even if you travel over every way, so deep is its report." See Charles H. Kahn, The Art and Thought of Heraclitus. An edition of the fragments with translation and commentary, translated by Charles H. Kahn, Cambridge University Press, Cambridge (MA) 1979 , p. 45.

15

Karl Jaspers, Allegemeine Psychopathologie, Springer-Verlag, Berlin 1949, p. 8. 
"It is fitting for men that they should make a logos more about the soul than about the body. For the perfection of the soul puts right the faults of the body. But strength of body without reasoning improves the soul not one whit." (B. 187)

While it is reported that Anaxagoras, differentiating between mind and psyche, instructed about the mind as follows:

"He [Anaxagoras] has written the following about Nous: 'The other things have a share of everything, but Nous is unlimited and self-ruling and has been mixed with no thing, but is alone itself by itself. For if it were not by itself, but had been mixed with anything else, then it would partake of all things, if it had been mixed with anything (for there is a share of everything in everything just as I have said before); and the things mixed together with it would thwart it, so that it would control none of the things in the way that it in fact does, being alone by itself. For it is the finest of all things and the purest, and indeed it maintains all discernment (gnōme $)$ about everything and has the greatest strength. And Nous has control over all things that have soul, both the larger and the smaller. And Nous controlled the whole revolution, so that it started to revolve in the beginning. First it began to revolve from a small region, but it is revolving yet more, and it will revolve still more. And Nous knew (egnō) them all: the things that are being mixed together, the things that are being separated off, and the things that are being dissociated. And whatever sorts of things were going to be, and whatever sorts were and now are not, and as many as are now and whatever sorts will be, all these Nous set in order. And Nous also ordered this revolution, in which the things being separated off now revolve, the stars and the sun and the moon and the air and the aether. This revolution caused them to separate off (...)."'16

In Timaeus, Plato argues that "soul" consist of elements, emphasizing the importance of harmonizing the soul, because in the case of the opposite, when the power of the immortal part is not aligned with the power of the mortal part, human beings see the soul and body as if they are separated. This masks away the true power of life, and causes internal disorder within human beings. ${ }^{17}$

From only a selection, it is clear that their understanding implies broader mereological connection of elements that form the biotic and the abiotic. "Dance" between life and death, between kinetics and statics, between body and soul, outline the complexity precisely in the discussion about the psyche, appearing to be an entangling polygon of the before mentioned poles. It is here where the analogy between good and evil can be drawn through the scheme of openness and closeness. The source of these relations already begins in the field of unconscious, and it is the repeating that embodies it into a drive underlying both individuals and society as a particular whole. I suggest that we should think of psyche as the moving energy whose openness and closeness, and the issues that are in that sense produced, such as psychic disorders, are defined by internal and external influences ordained by the mereological relation of elements. My goal was to point out that "soul", "mind", "psyche" is neither separated from body, nor it is in any way isolated from the rest of the atomarium of All-Oneness. Psyche is the outcome of the dialectics of the totality of body and the totality of mind, the "actualis" of the mind and body potentiality, a grounding synthesis which reveals itself as the presence of being itself, the energy governing all internal and external acts. In the next chapter, I will thus more specifically focus on the conclusion that evil should be, thus, considered as a psychic disorder in the sense in which psyche was described up to this point, and that we will not be able to deal with it invasively, for example, with morality enhancement, advanced prison systems or exclusion punishment, rather, with bringing them into the light of All-Oneness through nurture and education. 


\section{Evil and knowledge}

Considering conclusions presented in the previous chapter, in this one I explore a new hypothesis: that evil is related to the disorder of psyche, and that the outcomes of psyche can be related to the content of knowledge, concluding that evil can be considered as psychic disorder related to knowledge. In Emile, Rousseau wrote:

"We are born weak, we need strength; helpless, we need aid; foolish, we need reason. All that we lack at birth, all that we need when we come to man's estate, is the gift of education. This education comes to us from nature, from men, or from things. The inner growth of our organs and faculties is the education of nature, the use we learn to make of this growth is the education of men, what we gain by our experience of our surroundings is the education of things." 18

Goodness and honesty are characteristics that are taught, and so are evilness and dishonesty. They are not manifested merely because of genetic predispositions, they can be taught and they are not irreversible. Knowledge, conserved in the unconscious drive, accordingly produces the specific pattern of practice, producing, among other things, a distorted, evil psyche. Baudrillard observed:

"Nothing else can change anything in this world. Knowledge alone is capable of transforming the world, while at the same time leaving it exactly as it is. When you look at the world with knowledge, you realize that things are unchangeable and at the same time are constantly being transformed. You may ask what good it does us. Let's put it this way - human beings possess the weapon of knowledge in order to make life bearable. For animals such things aren't necessary. Animals don't need knowledge or anything of the sort to make life bearable. But human beings do need something, and with knowledge they can make the very intolerableness of life a weapon, though at the same time that intolerableness is not reduced in the slightest."19

I can provide two examples that give outlines to this theory.

First example is the general understanding of human beings as evil, which from Hobbes onward perpetuates itself as if it is true, and serves to constitute a type of world. In Leviathan, Hobbes wrote:

"For the rule of manners, without civil government, is the law of nature; and in it, the law civil, that determineth what is honest and dishonest; what is just and unjust; and generally what is good and evil. Whereas they make the rules of good, and bad, by their own liking and disliking: by which means, in so great diversity of tastes, there is nothing generally agreed on; but every one doth (as far as he dares) whatsoever seemeth good in his own eyes, to the subversion of commonwealth. Their logic, which should be the method of reasoning, is nothing else but captions [quibbles] of words, and inventions how to puzzle such as should go about to pose them." 20

Fromm showed how this logic perpetuated itself all the way to the 20th century, and he heavily criticized how we adopted this approach as if it's in our

16

B12 Simplicius in Phys. 164.24; 156.13. See Anaxagoras of Clazomenae, Fragments and Testimonia, translated by Patricia Curd, University of Toronto Press, London 1992, pp. $22-25$.

17

Cf. Marko Tokić, Život, zdravlje i liječništvo u Platonovoj filozofiji [Life, Health, and Medicine in Philosophy of Plato], Pergamena, Zagreb 2013, p. 33.
18

Jean-Jacques Rousseau, Emile or On Education, translated by Allan Bloom, Basic Books, USA 1979, p. 38.

19

J. Baudrillard, The Intelligence of Evil or the Lucidity Pact, p. 175.

20

Thomas Hobbes, Leviathan or The Matter, Forme and Power of a Common-Wealth Ecclesiasticall and Civil, Oxford University Press, Oxford 1998, p. 445. 
nature, showing in detail many methodological mistakes which led us to believe so. ${ }^{21}$ In Theodicy, Leibniz turned focus to a statement by Maimonides that supports Fromm's analysis:

"Maimonides adds that the cause of their extravagant error is their supposition that Nature was made for them only, and that they hold of no account what is separate from their person; whence they infer that when something unpleasing to them occurs all goes ill in the universe."22

In an agreement with Fromm and Maimonides, I conclude that the mosaic of our behaviour cannot be determined by a relative judgment underlined with selfish tendencies coming from particular members of any community, rather, only by their tendency towards co-bearing. Fake images of the world we agree about come into existence through cognitive deficit in the sense of deviant possession of matter, a cause of isolatory narcissism of the "wise" members of community, those that Rousseau exposed as frauds pushing community to "sign" the social contract - for it is wise, it secures our society - turning the entire false pretence into paradogma, a dogma which becomes embodied into a paradigm through practice. Pascal noted:

"Nature has made all her truths independent of one another. Our art makes one dependent on the other. But this is not natural. Each keeps its own place."23

Concepts such as Hobbes's homo homini lupus that get posited and practiced as the truth trumping and replacing other possibilities and practices is a direct enclosing of the harmonious relational grid of All-Oneness, of the biotic organismic whole, of its shining through the vile simplicity which is contained in concepts such as Hobbesian view on human nature, enwrapping human psyche into isolation from the evolutionary processes immortalized as All-Oneness. From such interpretations of the world come ideas such as "humanism" and "capitalism", the other two examples for my initial hypothesis. They represent the general system under which we live for centuries, both connected to Hobbesian perception of humankind.

We face "humanism", an epochal mask representing divine idea of noble, empathic, aesthetically perfected human being, an ideology pertaining to its false interpretation of human beings as the finest creation since the days of Cicero, ${ }^{24}$ while in reality it projected a truth completely opposite: sadism, narcissism, and violence as characteristics of species: geopolitical wars, genocides, biocides, class systems, racism, totalitarianism - all are supported by, and thriving thanks to religious organizations, institutionalized closeness operating for its own members exclusively, which only paints an ironic colours across the mask of humanism, with its idolatry praised on the altars, it's selling of forgiveness, it's inquisitions and tortures, it's list of forbidden books and excommunicated philosophers, burned at stakes or beheaded in front of their peons, it's religious bloodsheds across continents, and organized collecting of alms from the poorest and least able - never siding with the people, always siding with the governing force. Today we strive towards "transhumanism", and we haven't even reached humanism! It is a worrying trend that humanism is being turned into a culture of certain progress, as a doxa, an illusory moral constant every human being should feed on, only to plunge into the atomarium of narcissistic sanctuary - capitalism. Contract between religious structures and capitalism is only "natural", both are projecting their distorted behaviour as a natural order of things, both imply that we reached our final stage of development, and that what we have today is perfectly acceptable, a system of pseudodemocratic participation governed by the elite as 
the pinnacle of humanism - we need to go beyond, we need transhumanism! In fact, religious and political economic structures are united into a cohesive political organism whose atoms live conjoined in a forced society, but split into pens and driven by fear and hatred. Persist in a competition or vanish, obey the system or consider yourself to be a failure. Under the influence of "capitalist spirit" psycheness is being transmuted into pure matter, into body, creating false dualism. Materialized psyche can then be traded as commodity, can be quantified, which leads to the creation of fissures in the mereological harmony of society as an element of All-Oneness, ultimately causing a rudimentary nihilist approach to the understanding of All-Oneness. In order to maintain the ruling of capitalist's interest to keep the buyers intellectually and cognitively meagre, deficient, scarce, they invest into the control of education, creating an unbreakable magical circle. We are not meant to think with our own autonomous mind, rather, we are to follow the mainstream heteronomy, governed by, before any and all, religious institutions and government. It is as if Hobbesian negative anthropology became the prime motive of organization. Quite expected.

Both examples suggest to us that being evil and behaving evil is, in fact, normal and rational. Thus we are dealing with mereological corruption, in which evil behaviour is perceived as the pinnacle of rationality! Consider Lütz's observation:

"If you see the evening news as a psychiatrist and psychotherapist, you are regularly irritated. It's all about warmongers, terrorists, murderers, white-collar criminals, ice-cold types of accountants, and shameless egomaniacs - and nobody treats them. Indeed, such figures are considered completely normal. When I think of the people with whom I spent my day - touching dementia patients, thin-skinned addicts, highly sensitive schizophrenics, staggering depressives and rousing manicists - sometimes a dreadful suspicion creeps into my head: We treat the wrong people! Our problem are not the crazy, our problem are the normal!" 25

Intentional unconscious is an ideal incubator for evil-doing, able to develop into an instinct for evil. Thus, the emphasis is on consciousness aware of the All-Oneness, on being present as it, but as merely a part of it, and as such being able to identify and alter the "necessary" mechanisms of evildoing, which is nothing but entropic disturbance of the cosmic harmony of the All-Oneness, mereological fractionalization. Reparation is achievable by self-birth because, before any empirical confirmation, evil develops first and foremost in thoughts, in consciousness, thus in psyche, and we instruct ourselves towards different ending by understanding root cause of this negative development, the "fake nature" of our kind. Kant observed:

21

Cf. Erich Fromm, Anatomy of Human Destructiveness, Holt, Rinehart and Winston, New York 1973.

22

Gottfried Wilhelm Leibniz, Theodicy. Essays on the Goodness of God, the Freedom of Man and the Origin of Evil, translated by E. M. Huggard, BiblioBazaar, Charleston 2007, p. 291 .

23

Blaise Pascal, Pascal's Pensées, translated by T. S. Eliot, The Project Gutenberg EBook 2006, p. 12
24

It was Cicero who described it so in his $D e$ officis, ideas that were later adopted by the leading names of Renaissance, only to confirm the paralysis of its teleological reach. How did the anthropocentric Renaissance actually occur, in its, in fact, poor social reality, and to what did it lead to?

25

Manfred Lütz, Irre! Wir behandeln die Falschen. Unser Problem sind die Normalen, Gütersloher Verlaghaus, Gütersloh 2009, p. 10. 
"When a thoughtful man has overcome incentives to vice and is aware of having done his often bitter duty, he finds himself in a state that could well be called happiness, a state of contentment and peace of soul in which virtue is its own reward." 26

Thus, the question is the following: if most powerful institutions, such as religious organizations and government, are so effective at biopolitical control, is it possible to tailor anew the established selfish nature into the paradigm of All-Oneness? It is certain that this is achievable by deliberating ourselves from conceptual enframing, by opening ourselves to the different and other It is how we learn about goodness and become goodness ourselves. Phenomenon of consciousness is crucial in perceiving eccentrically positioned mereology of the interrelations of beings, awareness of the suffering of others, and the prevention of suffering through the energy of openness. We can think of goodness as the light of cognition which understands All-Oneness, and by being a manifestation of openness one actualizes the purpose of all beings, whereby evil is closeness as the darkening of the mind, a psyche which manifests itself as the falling back in progress, embodiment of thanatos. Plotinus believed that:

"Good must be completely sufficient to itself and without need of anything else at all, what other nature than this could anyone find, which was what it was before the others, when there was not yet any badness? But if the evils come later, in things which do not participate in this Good in any way at all, and on the very last and lowest level, and there is nothing beyond the evils on the worse side, the evils would be opposed to it without any middle term for the opposition. This then would be the Good; for either there is no Good at all, or, if it is necessary that there is, it would be this and not something else. But if someone says that there is not, then there would be no evil either; so things would be by nature indifferent for our choice; but this is impossible. But what others call goods are referred to this, but it itself is referred to nothing. What then does it make, if it is like this? It made Intellect, it made life, and from Intellect the souls and all else that has a share in reason or intellect or life. (...) And certainly each of these effects something for those of which they are the good, some arrangement and ordered beauty, some already life, and some thought and living well, but for Intellect the Good effects something, the Good which we maintain comes also to this, both because its active actuality comes from it and because now also it gives something called light: what this is, we shall see later."27

Loss of awareness regarding the state in which are others creates a mental involucre of closeness which prevents the agent from connecting with the AllOneness. This develops an unhealthy psyche which manifests itself as core narcissism. Baudrillard wrote:

"To speak evil is to describe the growing hegemony of the powers of good and, at the same time, their inner faltering, their suicidal crumbling, their reversion, their outgrowth and separation into parallel universes once the dividing line of the Universal has been crossed." 28

In a sense, we can draw parallel with the Greek-Heideggerian understanding of truth as "unconcealedness" and "unclosedness", which is directly opposite of untruth or a lie, both being manifestations of wrongness, if not evil. Connection between purity and openness is clear, psychic purity implies harmony with the revealed All-Oneness which guarantees the ordered communication between mereological elements. Again, Baudrillard is sharp here, quoting an interesting explanation of the good-evil opposition by Mishima:

"Good wants always to speak itself, whereas evil is bound up with secrecy. (...) The special quality of hell is to see everything clearly down to the last detail." 29

Thus, healthy psyche presupposes harmony of atoms that create stabile political communities which are not depending on strict hierarchy and controlled distribution of power because their only reference to harmonious existence is the open awareness of the unconcealed All-Oneness. It reflects a valid mereo- 
logy of psyche, standing in opposition to the entropic dismemberment which for its direct causes has, on the one hand, for example, irreversible psychic breakdowns, and on the other hand, for example, willingness to commit crime, ${ }^{30}$ thus lack of empathy. Yet evil is most rebuffingly bred under the influence of leaders of the political (community) order, with the micro-element being the household, that is, family. The stronger their influence, the faster is the growth of evil-doing. Totalitarian regimes of 20th century are perhaps the best examples, and so is the prosecution of "witches" in the Middle Age. Being taught to follow naturally grants the institutions the power to influence their followers, and thus their malice reflects in the people under them. Foucault wrote extensively on that matter, though of course in the context of his own understanding of power as relational, rather than hierarchical and centralized, and what we can conclude from his studies that he relates to how servants of the system see the order within - as finite, enclosed, and necessary, thus normal. As the need to imitate and repeat increases, so does the psychic entropy of evil. In return, the abundance of it is being conserved and carried further as the part of unconscious drive, confirming Hobbesian hypothesis. Every such presupposition, and the process of "breastfeeding" beings with values contained in this type of presuppositions which are in contrast with All-Oneness, by the sheer necessity of being opposite to All-Oneness produces fertile ground for systematization - normalization - of evil. These consequences do not apply to human beings strictly, but precisely because of the mereological network of energy, it applies to entire biosphere. Climate change caused by human beings is one obvious example. Buber observed:

"When Thou is spoken, the speaker has no thing for his object. For where there is a thing there is another thing. Every $I t$ is bounded by others; It exists only through being bounded by others. But when Thou is spoken, there is no thing. Thou has no bounds." 31

Serbian release of Buber's Ich und Du contains an additional epilogue that Buber wrote in 1957 in Jerusalem. The following question is interesting:

"If we can be in I-Thou relationship, as was said in the book [I and Thou], not only towards other people, but also towards beings and things we meet in nature, what then makes a crucial difference between some and others? More precisely: if factual encompassing mutuality conditions the I-Thou relationship of both, I and Thou, how can a relation towards nature be understood as such? To be exact: if we are to accept that both beings and things of nature that we meet as our Thou guarantee some sort of mutuality, what is then the character of this mutuality $(\ldots)$ ?"’32

Character of this boundness belongs to the category of integrativity, which is the core mechanism of All-Oneness. It produces the mereologically structured

26

Immanuel Kant, The Metaphysics of Morals, translated by Mary Gregor, Cambridge University Press, Cambridge 1991, p. 183 [377].

27

Plotinus, Enneads, translated by A. H. Armstrong, Harvard University Press, Cambridge (MA) 1989, VI. 7. 23. 5-20; VI. 7. 25. 25-30.

28

J. Baudrillard, The Intelligence of Evil or the Lucidity Pact, p. 24.

29

Yukio Mishima, The Temple of the Golden Pavilion, translated by Ivan Morris, Vintage, London 2001, p. 95, cited by J. Baudrillard,
The Intelligence of Evil or the Lucidity Pact, p. 180.

30

Not in the sense of obeying law, but in the sense of being violent and oppressive. 31

Martin Buber, I and Thou, translated by Ronald Gregor Smith, T. \& T. Clarke, Edinburgh 1937, p. 4.

32

Martin Buber, Ja i ti [I and Thou], translated by Jovica Aćin, Kultura, Beograd 1977, p. 130 
morality as the paradigm of action. Every living being carries the potency for death, every bleeding being carries the potency to suffer, and thus human beings as the "crest of evolutionary game" carry the responsibility and duty to reflect upon All-Oneness and teach about it, to endorses it through all the living and non-living that makes the biosphere for what it is. Here are the grounds for the critique of oil exploitation, forest destruction, species extermination, air intoxication, and seabed ruination, for the purpose no other but civilizational pleasantries, which again in the latest form of capitalism can be truly observed as the continuation of the alienation from our substantial "being humane".

Treatment of beings which are "not normal" has a history quite opposite to the idealized humanism, and as such is a perfect example for understanding the intentional unconscious of evil-doing. Here I specifically point at development of psychiatry because it is my narrower field of interest within bioethical research. Methodologically, the approach to "abnormal" was marked by removal from the public area, a practice that established itself for every social misfit ruining the image of power structure. Foucault noticed:

"Leprosy disappeared, the leper vanished, or almost, from memory; these structures remained. Often, in these same places, the formulas of exclusion would be repeated, strangely similar two or three centuries later. Poor vagabonds, criminals, and 'deranged minds' would take the part played by the leper, and we shall see what salvation was expected from this exclusion, for them and for those who excluded them as well. With an altogether new meaning and in a very different culture, the forms would remain essentially that major form of a rigorous division which is social exclusion but spiritual reintegration." 33

Moreso, it has the same behavioural formula as banishing demons. Lütz reports about the attitude towards mentally ill prior to the establishment of psychiatric institutions:

"Certainly, there were clearly mentally ill persons in those times as well. But they were not perceived as such. For psychiatry was not even invented yet. And so mentally ill people were possessed by evil spirits or were simply considered criminal, and treated accordingly. Some were displayed on fairs. Mentally ill poet Hölderlin was, since the year 1807 until his death in 1843 in Tübingen, in spite of the friendliness of the innkeepers, basically kept as an animal." 34

The irony of humanism reached its peak when António Egas Moniz was awarded a Nobel prize in 1949 for his "discovery" and application of lobotomy, ${ }^{35}$ which was at the time accompanied by the practice of excessive electroshock therapy, and insulin shock therapy (insulin coma). ${ }^{36}$ Yet the process of "humanization" of psychotherapy reached its pinnacle in the last several decades, with the expansion of the use of psychopharmacs, represented as the scientific triumph over psychic illness. Croatian psychiatrist Robert Torre, who started a type of anti-psychiatry movement in Croatia, wrote extensively on this issue. He explained how treatment with psychopharmacs was promoted:

"Thus, with the birth of the first generation of antipsychotics begins the first "psychopharmacal revolution', which brings nearly a century of asylum psychiatry to an end, and the deinstitutionalization of numerous psychiatric patients started. Massive state mental hospitals begin to unload and enter the adaptation process. Year 1955 is considered the birthday of contemporary psychiatry, a year during which the first antipsychotic chlorpromazine (in the United States under factory name Thorazine, in Europe as Lagractil) was introduced, marketed as 'miraculous cure for schizophrenia'." 37

However, Torre describes later in the chapter, the practice was again far from honest:

"The very title 'antipsychotic' is intentionally tendentious, wrong, the result of poignant market branding, because it suggests that it is about a pharmac that is an antidote for psychic disorders. 
The notion of psychotic creates an impression that it is about a psychpharmaceutical antibiotic for a psychotic bacillus schizophrenococcus, that is, that it effectively cures a disease." 38

In all mentioned instances, these practices ultimately demonstrate an attempt to fully control the presupposed norm of our behaviour, twisting the telos of knowledge. Consider Laing's observation:

"A man who prefers to be dead rather than Red is normal. A man who says he has lost his soul is mad. A man who says that men are machines may be a great scientist. A man who says he is a machine is 'depersonalized' in psychiatric jargon. A man who says that Negroes are an inferior race may be widely respected. A man who says his whiteness is a form of cancer is certifiable." 39

Thusly, we are dealing with the wrong base of the system in use. We ought to reform the "radix" of our system of thought. In order to revert the process of the fertilization of evil-doing, to reduce the psychic entropy of evil, one needs to invest their energy into nothing but educating children and youth, which also means fighting for the educational institutions to remain free of market trading, and protected from the techno-scientific lobbyists because precisely these two spheres of contemporary activity are antagonists in the game of civilizational enframing that secludes itself away from All-Oneness, and in it lies the simple motive of exploitation, the adaption of the general law of communication to private, particularized preferences. It is the process of negating pluriperspectivity which shines from the mereological structure of All-Oneness. Instead, in order to properly reform the educational processes, one needs to find an orientation in the absolute which holds itself true, which is, in a sense, corresponding to all beings altogether. I claim that it is AllOneness that can serve us as such orientational concept, and that it grants us stronger foothold for morally correct relations between living beings. Kant concluded:

"Ethical duties must not be determined in accordance with the capacity to fulfil the law that is ascribed to man; on the contrary, man's moral capacity must be estimated by the law, which commands categorically, and so in accordance with our rational knowledge of what men ought to be in keeping with the Idea of humanity, not in accordance with the empirical knowledge we have of men as they are. These three maxims for scientific treatment of a doctrine of virtue are opposed to the following ancient dicta: 1) There is only one virtue and one vice. 2) Virtue is

33

Michel Foucault, Madness and Civilization A History of Insanity in the Age of Reason, translated by Richard Howard, Routledge, New York 2001, p. 6.

34

M. Lütz, Irre!, p. 54.

35

For more detail on the zombie effects of lobotomy see: Jay L. Hoffman, "Clinical observations concerning schizophrenic patients treated by prefrontal leukotomy", New England Journal of Medicine 241 (6/1949), pp. 233-236. doi: https://doi.org/10.1056/ nejm194908112410604.

36

For more details on the use of psychosurgical procedures before the use of psychopharmacs, such as electroshock therapy - today still lacking the complete understanding of what it does to the psyche - see: Victor W. Swayze, "Frontal leukotomy and related psychosurgical procedures in the era before antipsychotics (1935-1954): a historical overview", American Journal of Psychiatry 152 (4/1995), pp. 505-515. doi: https://doi. org/10.1176/ajp.152.4.505.

37

Robert Torre, Prava istina o psihijatriji: kako zaustaviti planetarnu epidemiju uzimanja psihofarmaka [Real Truth about Psychiatry: How to End the Planetary Epidemics of Taking Psychopharmacs], Profil, Zagreb 2014, p. 28 .

38

Ibid., p. 36.

39

Ronald David Laing, Divided Self, Penguin Books, London 1969, pp. 11-12. 
the observance of the middle way between opposing vices. 3) Virtue (like prudence) must be learned from experience." 40

I claim that the danger of monoperspective domination of an individual idea is trumped by the concept of All-Oneness, and that it battles the nihilism of plurality which infects progress and evolution, creating the destrolution ${ }^{41}$ of meaningful being in the world. But such turnover requires an appropriate platform. In the concluding chapter, I would like to emphasize the importance of the approach developed within the project of integrative bioethics, which started as a reaction to the mereological distortion of the core knowledge enterprise: science.

\section{Palingenesis of All-Oneness and the luminance of integrative bioethics}

Eventually, it was the epistemic separation from All-Oneness that produced the terrors of 20th century society, the collaboration between uncritically supported techno-scientific development, boundless political power, and financial exploitation. After Cartesian influence that looked at the world through mathematical lenses, furtherly fuelled by capitalism, especially its negative influence on the perception of animals, it was Bacon who institutionalized the "knowledge is power" mantra. Discussing the nature of contemporary science, Čović offered a solid explanation for what happened with the perception of the role of science:

"Within the horizon of Socratic and Aristotelian thought we established a connection between knowledge and goodness. In contrast, the analysis of Bacon's instauratio magna project demonstrated how new science is, from its very beginning, constituted from the other side of good and evil, which was later fully confirmed through the establishment of modern science. In other words, from science, which represents the dominant form of knowledge in our age, moral dimension is excluded, a consideration for good. But it was not just moral dimension that was excluded, so were other integrative dimensions of knowledge, which eventually resulted in their dwindling away from the contemporary world grounded in such knowledge, and by that being reduced to its techno-scientific image." 42

It is obvious that the mentioned techno-scientific image does not contain the mereology of All-Oneness, which makes sense as long as we do not forget that we are operating in the framework of capitalistic materialism, and such ideas can only shake their operational structures. Discussing these issues in the context of Hans Jonas' philosophy, Jurić concluded:

"In any case, on the basis of Jonas' 'choice from the history of modern science and technics' can be concluded that their differentia specifica, in contrast with pre-modern science and technics, primarily consists of, firstly, the role of science in constructing technical devices (scientific research, solutions, planning and requests) increases, and secondly, that, in spite of previously stated, but precisely because it - technics dictate the development of sciences, scientific reasoning, and finally the very scientific knowledge." 43

Within humanities, it was the project of bioethics that began to provide resistance, and suggest orientation for overcoming the situation. Perušić elaborated:

"New epoch reveals itself in a simple, dire need to change the way of thinking, considering the facticity into which human kind led itself, but which eludes it in numerous ways. In the new area of civilizational advancement two processes developed - globalization and heterogenization - resulting in further fragmentation of social reality completely rid of adequate thinking, and thus producing factual impossibility to find valid approaches to issues: finding appropriate way to ask a question, appropriate way of considering responses, and, finally, carrying out appropri- 
ate solutions. Bioethics, originating in the heat of these changes in spite of them, for that very reason became recognized and institutionalized by the end of 20 th century as a leading scientific discipline in the field of humanities." 44

In the first decade of 21 st century the project of integrative bioethics started. One of the fundamental critiques coming from integrative bioethics was focused on techno-mania which results in the robotizing and alienation of beings from their being. Integrative bioethics attacked what Oswald Spengler confirmed as the dominant practice:

"With the growth of the towns, technics became bourgeois. (...) Finally, with the coming of rationalism, the belief in technics almost becomes a materialistic religion. Technics is eternal and immortal like God the Father, it delivers mankind like God the Son, and it illumines us like God the Holy Ghost. And its worshipper is the progress-philistine of the modem age which runs from Lamettrie to Lenin." 45

From Lamettrie and Lenin aporia continues all the way to greedy hands of pharmaceuts and their patients who see their technological god in psychopharmacs, saving them by chemically induced transcendence from the state of pain into the state of floral hedony and ataraxy, instead of achieving personal catharsis. Torre explains how their approach to healing psyche is a trap, mainly that they use

“... techno-pharmaceutical substances which mainly do not cure, but rather they induce artificial psychic states that supress or mask unwanted states, further creating physical and psychic addition, prevent patient's spiritual initiative, and cause heart diseases, brain atrophy and diabetes." 46

Technics which is advanced by science without being orchestrated by moral reasoning by sheer necessity leads to destruction. In the context of psychiatry care, there isn't much that comes out technologically augmented treatment, other than turning living beings into machines. Here, bioethics, most especially integrative bioethics with its consideration of the general value of Earth's plurality, come as a certain "post-technological Prometheus" who ought to banish enclosed darkness of technicized science with the burning flame of morality governed by the principle of All-Oneness. It provides us with the true meaning of the word "Us", under which I think of human beings, plants, animals, and the rest of the biosphere. It is the ethos of integrative bioethics that provides ground for the palingenesis of All-Oneness, it's sensibility for

40

I. Kant, The Metaphysics of Morals, pp. 205206 [404-405].

41

Destrolution is the term that was coined by Ante Čović in 2017. It means "systematic destruction", and it implies that any destrolutive process is motive-driven, and thus it is a project. See Ante Čović, "Destrolucija" ["Destrolution"], Universitas (April 2017), p. 11 .

42

Ante Čović, Etika $i$ bioetika [Ethics and Bioethics], Pergamena, Zagreb 2004, p. 63.

43

Hrvoje Jurić, Etika odgovornosti Hansa Jonasa [Hans Jonas' Ethics of Responsibility], Pergamena, Zagreb 2010, p. 123.
44

Luka Perušić, Ivan Bauernfreund, "Na putu Studentske bioetičke radionice, osvrt na razvoj, ulogu i značaj Bioetičkog inkubatora" ["On the Path of Student Bioethics Workshop: Review of Development, Role, and Importance of Bioethical Incubator'], Holon 5 (1/2015), pp. 164-202, p. 169.

45

Oswald Spengler, Man and Technics. A Contribution to a Philosophy of Life, translated by Charles Francis Atkinson, Greenwood Press, London 1932, p. 43.

46

R. Torre, Prava istina o psihijatriji [Real Truth about Psychiatry], p. 22. 
openness. Rudimentary, I dare to say that human beings are, in fact, zoon bioethikon, bioethical animal with its teleological strive towards life as life, not just one's own. Speaking in the context of the fundamental nature of AllOneness, integrative bioethics carries the power of pulling the psyche out of solipsistic narcissism towards the domain of deontic objectivity, and allowing for the suffering psyche to recover and achieve autonomous self-productive existence guided by the need to contribute to the well-being of entire planet. Separation from the being of logos - closeness - belonging to each particular situation, governed by All-Oneness, creates the schizophrenic collision of perceptive atomary, known only to human beings. The current is very clear: polluted and ravaged planet implies polluted and ravaged psyche.

In conclusion, to confirm: evil is the product of psychic entropy, but so it is its cause. It is operating in terms of the energy of closeness, defied by the palingenesis of the originary harmonious structure of All-Oneness. For life, if it is, by sheer necessity leans towards centripetal force of openness, regardless of the number of thanatological epochs, rings that rose in the mereology of time. It is important to underline that so far only human beings carry the potency to consciously sum up the mereology of All-Oneness, and that for this reason only it is our duty to give birth to and transfer the knowledge to other atoms of All-Oneness, between them ultimately securing goodness. 


\title{
Luka Janeš
}

\section{Paradogma psihičke entropije zla i palingeneza Svejednote}

\begin{abstract}
Sažetak
Cilj je rada ukazati na neadekvatan opći teorijski pristup percepciji zla, čime se doprinosi permanenciji »zla u svijetu«. Analiza će se provesti usmjeravanjem na logijski neprecizno usvajani i razmatrani antropocentrički i romantičarski odnos dobra i zla kroz diskusijski uvriježene parove poput vrlina-grijeh, raj-pakao i bijelo-crno. Iznosi se koncept koji tumači zlo kao apriorno psihički i epistemički fenomen kakav transmutacijom kroz navedene kategorije prerasta u problem morala. Javlja se u okviru društvene (političke) zajednice kao omjer energije »otvorenosti« $i » z a t v o r e n o s t i \ll$. Parnjakom otvorenost-zatvorenost zamjenjujem sve tradicionalne parnjake i oprimjerujem ga na temelju analize narcizma. Narcizam poimam kao rezultat manjkavosti znanja bivstvujućih koji se potencira srdžbom i strahom u odnosu na sebstvo i onemogućuje spoznavanje Svejednote, mereološkog principa koji pod sobom podrazumijeva cjelinu biotičke zajednice. Doprinos rada sastoji se od ukazivanja na postupke umanjivanja zla u svijetu.
\end{abstract}

\section{Ključne riječi}

psihička entropija, Svejednota, narcizam, zlo, integrativna bioetika, mereologija, otvorenost, zatvorenost, svjetlost, integrativna bioetika

\section{Luka Janeš}

\section{Das Paradogma der psychischen Entropie des Bösen und die Palingenese der Alleinheit}

\section{Zusammenfassung}

Das Ziel der Arbeit ist es, auf eine inadäquate allgemeine theoriehafte Herangehensweise an die Wahrnehmung des Bösen hinzuweisen, wodurch der Permanenz des „Bösen in der Welt“ beigetragen wird. Die Analyse wird durchgeführt, indem der Schwerpunkt auf die durch Logie unpräzise angeeignete und betrachtete anthropozentrische und romantisierende Beziehung zwischen Gut und Böse gelenkt wird, und zwar durch diskussionsbezogen eingewurzelte Paare wie Tugend-Sünde, Paradies-Hölle und Weiß-Schwarz. Es wird ein Konzept dargelegt, welches das Böse als ein apriorisch psychisches und epistemisches Phänomen deutet, das infolge der Transmutation durch die angeführten Kategorien in ein Problem der Moral hinüberwächst. Es erscheint im Rahmen einer sozialen (politischen) Gemeinschaft als Verhältnis der Energie der „Offenheit" und „, Geschlossenheit“. Durch die Paarbildung Offenheit-Geschlossenheit ersetze ich sämtliche traditionellen Paarbildungen und exemplifiziere die angebrachte Paarbildung aufgrund der Analyse des Narzissmus. Den Narzissmus begreife ich als Ergebnis des Wissensmangels bei Seienden, das durch Zorn und Angst in Bezug auf das Selbst potenziert wird und die Erkenntnis der Alleinheit unterbindet, eines mereologischen Prinzips, welches unter sich die Gesamtheit der biotischen Gemeinschaft mit einbegreift. Der Beitrag der Arbeit besteht darin, auf die Vorgehensweisen zu verweisen, welche das Böse in der Welt reduzieren.

\section{Schlüsselwörter}

Böses, Narzissmus, Offenheit, Geschlossenheit, psychische Entropie, Alleinheit, Mereologie, Licht, Integrative Bioethik

\section{Luka Janeš}

\section{Le paradogme de l'entropie psychique du mal et la palingénésie du Tout-Un}

\section{Résumé}

Le but de ce travail est de montrer que l'approche théorique et générale de la perception du mal, par laquelle on contribue à la constance du "mal dans le monde », est inadéquate. Ce travail procédera à l'analyse de la relation du bien et du mal anthropocentrique et romantique, que l'on s'est approprié et qui a été analysée de manière imprécise d'un point de vue logique, 
à travers des couples de discussion ancrés tels que valeur-péché, paradis-enfer et blanc-noir. Le concept qui interprète le mal en tant que phénomène psychique et épistémique apriorique comme la transmutation est exposé à travers les catégories mentionnées dans le problème de la morale. Il apparaît dans le cadre de la communauté sociale (politique) comme un rapport de l'énergie d'" ouverture » et d'" fermeture ». Je remplace, par le couple ouverture-fermeture, tous les couples traditionnels et j'applique ce couple à l'analyse du narcissisme. Je conçois le narcissisme comme le résultat d'un défaut de connaissances des étants, qui s'élève à la puissance par la colère et la peur sur le soi et ne permet pas la connaissance du Tout-Un, principe méréologique qui suppose l'ensemble de la communauté biotique. Ce travail contribue à montrer les procédés qui réduisent le mal dans le monde.

\section{Mots-clés}

mal, narcissisme, ouverture, fermeture, entropie psychique, Tout-Un, méréologie, lumière, bioéthique intégrative 